THE CRISIS OF CAPITALIST DEMOCRACY 



\section{THE CRISIS OF CAPITALIST DEMOCRACY}

Richard A. Posner 
Copyright (C) 2010 by the President and Fellows of Harvard College All rights reserved

Printed in the United States of America

\section{Library of Congress Cataloging-in-Publication Data}

Posner, Richard A.

The crisis of capitalist democracy / Richard A. Posner.

p. $\mathrm{cm}$.

Includes bibliographical references and index.

ISBN 978-0-674-05574-2 (cloth : alk. paper)

1. Capitalism. 2. Democracy. 3. Financial crises. I. Title.

HB501.P646 2010

$330.12 ' 2$-dc22 2009050929 